 \\ Journal of \\ Human, Earth, and Future
}

ISSN: 2785-2997

Vol. 2, No. 2, June, 2021

\section{Administrative Capacity of Local Government in Responding to Natural Disasters in Developing Countries}

\author{
Nguyen Van Quang ${ }^{1 *}$, Doan Trieu Long ${ }^{1}$, Nguyen Dung Anh ${ }^{1}$, Thanh Nguyen Hai ${ }^{2}{ }$ \\ ${ }^{1}$ Academy of Politics Region III, Ho Chi Minh National Academy of Politics, Vietnam \\ ${ }^{2}$ Institute of Leadership and Public Policy, Ho Chi Minh National Academy of Politics, Hanoi, Vietnam
}

Received 24 February 2021; Revised 11 May 2021; Accepted 19 May 2021; Published 01 June 2021

\begin{abstract}
The important role of local government in the socio-economic development of localities has been confirmed in many domestic and foreign studies. But the role of the government in drought adaptation has often received little attention and analysis in domestic studies. Approaching from the local tectonic government model, the article argues that local government is an important link to promoting adaptive capacity at the local level of Vietnam and the Central Highlands provinces provide a case study that is typical for research and development of the capacity to adapt to drought and natural disasters for local authorities in Vietnam. Analysis of adaptive capacity through case studies in local government in the Central Highlands provinces shows that capacity is a major challenge for local governments here. The paper recommends that it is necessary to further expand the initiative and role of local authorities in guiding and promoting adaptation for communities and local people.
\end{abstract}

Keywords: Management Capacity; Local Government; Natural Disasters; The Central Highlands; Vietnam.

\section{Introduction}

Improving the governance capacity of local governments is considered one of the most urgent needs for developing countries in the context of increasing globalization and responding to fierce changes in human damage to the natural environment based on promoting local capacity [1]. However, research papers on governance capacity-building focus mainly on communities and local people, with an emphasis on governance capacity-building for local governments at all levels, a link between the two groups. The importance of socio-economic development and disaster resilience seems to be on the agenda in emerging countries, as local government contributions increasingly become important in organizing the implementation of policies and addressing the legitimate interests of the people, implementing social security policies [2].

The Central Highlands region is considered the most important strategic region in Vietnam in terms of politics, economy, society, security, and national defense. The whole region has five provinces, namely Dak Lak, Gia Lai, Kon Tum, Dak Nong, and Lam Dong, with a natural area of $54,470 \mathrm{~km}^{2}$, accounting for $1 / 6$ of Vietnam's area, and a population of nearly six million people, with 61 administrative district level administration, 727 commune-level administrative units (283 communes with a large number of ethnic minorities living in), 7,824 villages, hamlets, and

\footnotetext{
* Corresponding author: nvquang.hcma3@gmail.com

$>$ This is an open access article under the CC-BY license (https://creativecommons.org/licenses/by/4.0/).

(C) Authors retain all copyrights.
} 
villages (with 2,764 villages and hamlets of ethnic minorities) are self-governing organizations in the residential community. The Central Highlands is considered a land that preserves the cultural traditions of the long-standing indigenous community with its own nuances. However, before the process of international integration and the impact of the fourth industrial revolution, the Central Highlands was strongly influenced, leading to a profound change in the way of economic and social governance response to natural disasters, including very worrying trends because the local governance capacity of the leadership team has not kept up with these impacts [3].

It is noteworthy that, so far, studies in Vietnam have focused more on global and national governance than on local governance [3]. The study in the Central Highlands provinces of Vietnam provides a case study for improving local governance capacity in disaster response. On that basis, this study focuses on explaining the governance capacity of local authorities in the Central Highlands, the situation of natural disasters and specific actions to respond to natural disasters in recent times, thereby providing discussions and some recommendations to contribute improve local governance capacity in the Central Highlands of Vietnam in response to natural disasters.

\section{Theoretical Background}

\subsection{Local Administration}

In the 1980s of the twentieth century, a number of European countries have achieved many encouraging results in local governance, from these results, in 1985, the European Union adopted the Convention on self-governance. Since then, countries wishing to join the European Union must accede to this convention [3]. These results have gone viral and have become the subject of widespread interest outside the European Union, with some recommendations being made for developing countries that need to decentralize governance to local governments with the implication of strengthening local governance capacity [4]. Localities are more self-determined. However, Wilson (2000) [5] argues that local governance in poor or developing countries is rather weak, so governance decisions are still made by higher levels of government, local communities, social organizations, economic organizations, professional organizations, ... citizens living and operating in the local territory have a very vague role in the relationship between people and local authorities. Local government has proved to be less effective, so governments need to reduce their role in intervening in the activities of the localities. It is only until a certain time when the localities are capable of governance that they will decentralize to make local governance truly effective and promote democracy.

These recommendations were ignored. When decentralization and governance of local governments proved ineffective, people doubted the real governance capacity of local governments. Only practical requirements can be met when building a system of principles to shape the local government system [3] and 8 principles: mobilizing the participation of actors in the commune. Association into state governance, management by law; transparency; adaptive and flexible; orientation and consensus; fair and equal; effectiveness and efficiency; accountability is well enforced [6]. Anh (2014) [7] believes that local governance is only really promoted when: 1) the political and legal system respects the freedom and legal and legitimate rights of the people; 2) the law must be respected; 3) there is a clear, objective, and scientific division of power; 4) there is the participation of many actors in the process of planning and organizing the implementation of policies; and 5) public resources must be managed strictly and transparently.

Given concerns about constraints on local governance in developing countries, recommendations to reduce the role of government in the economy have been accompanied by proposals to decentralize and for local government to If local governments perform a role of local governance, then localities themselves need to prepare, but there should be no duplication of models between countries and even within different regions of the same country [8]. For local governments to have sufficient local governance capacity is a matter of discussion in most countries undergoing decentralization, where the priority strategy for construction and training efforts leadership team, civil servants must first be servants [9]. They need to be provided with leadership and management skills to develop different projects [10].

Debates about local governance have so far been a topical topic, but they all acknowledge that local governance capacity manifests in the aspect of government being closer to the people, creating conditions for people to participate to focus more on local work, strengthen the responsibility of local leaders in making and implementing government decisions, essentially focusing on the self-governing capacity of local governments, promoting the role of the local government. The role of many actors participating in community affairs [2]. With such an approach, local governance is concerned with planning and implementing local economic and social development processes, defining strategic vision, managing affairs, exploiting and using effectively using local resources, in organizing law enforcement, implementing local government decisions, and at the same time taking care of the people's legitimate and legitimate rights and interests of social security policies, creating conditions for local people to participate in state affairs [10]. Moreover, with the development of digital technology, local governance must also have digital technology management capabilities [11]. 


\subsection{Governance Capacity of Local Government}

In developed countries, local governance capacity is very developed, decentralization and initiative are very high, whereas in slow and developing countries, local governance capacity is very limited, so when implementing Current decentralization causes concerns due to the weak bureaucracy and staff in many aspects [5]. However, in order to achieve good local governance, this process requires localities to actively learn, constantly expanding their experiences through practice [8].

According to Brinkerhoff (2008), local governance capacity is expressed on three levels: At the first level, the leadership activities show authoritarianism, the voice of the people is less concerned, the identification and implementation of functions and operational tasks of the apparatus and construction are weak. At the second level, the apparatus is not effective, mainly maintaining stability, people's participation in policy processes is not clear, consensus, accountability, transparency, the operating apparatus is only effective in certain aspects. At the third level, all stages of the policy process are well implemented, with high independence and self-responsibility, with the participation of the people in most of the policy process, towards consensus, responsibility and accountability, accountability, transparency, efficiency, efficiency, responsiveness, fairness, consideration for all and compliance with the law [7].

According to Grindle (2009) [12] local governance capacity includes smaller components: institutional capacity, organizational capacity, implementation capacity, technical capacity, political capacity.

- Policy (institutional) capacity: to promptly formulate and issue decisions to meet practical requirements.

- Organizational capacity: the effective and efficient operation of the administrative apparatus is strictly defined, the internal institutions are clearly and transparently regulated, the connection with closely related departments.

- Implementation capacity: proactive in implementing effective decisions on the basis of existing resources, towards sustainability.

- Technical/technological capacity: the readiness and capacity to capture and apply technological knowledge and skills to the policy process to bring about effective governance.

- Political capacity: mastering and taking the initiative in resolving conflicts, responding well, being flexible and flexible to the needs and interests of the people.

The formation of local governance capacity depends on practical capacity, political qualities, professional knowledge and skills, public service ethics, and local governance capacity also depends on participation of people, political, economic and social organizations [13].

Clearly defining the governance capacity of local governments and the factors affecting local governance capacity is necessary, contributing to building the governance capacity of local governments, by decentralization and decentralization is becoming increasingly common around the world, where governments cannot do everything for local governments. The government only governs the work that the local cannot or is not allowed to do, the government still has to lead the development strategy. However, the capacity of local governance in developing countries is a matter of limitations, but it is an irresistible trend. Therefore, countries need to pay attention to building local governments with sufficient governance capacity, good local governance will bring practical benefits to the people, in order to promote available resources most effectively, aiming the highest spending is for the people.

This study provides a theoretical and practical basis for the capacity of local governments at the provincial level in disaster risk management, exploring ways and means to strengthen disaster risk management capacity at the local level at the provincial level. Basing on the assumptions that local government governance is a shared responsibility and authority in the exercise of rights and functions. The database to carry out this study is exploited from available documents, data, reports and statistics of the five provinces in the Central Highlands of Vietnam.

The governance capacity of the local government is a broad category and involves many different aspects, but the study only focuses on the capacity to act in disaster risk management in the Central Highlands provinces of Vietnam as this is consistent with the study. The local governance capacities in this study are understood as:

- Research and forecast capacity of specialized agencies of local government related to natural disasters that may occur in the province.

- Capacity to develop plans, policies and regulations related to disaster risk management actions of local authorities.

- Capacity related to coordinated governance action: With regard to disaster management risks, local governments need to develop partnerships and build capacity for governance and build resilience. These partnerships can be both formal and informal, taking the form of vertical partnerships with other levels of 
government or horizontal relationships with other stakeholders; such as having the right to develop regional partnerships with other local governments in the same region for environmental actions, or regional cooperation for disaster recovery and reconstruction efforts.

- Local governance capacity of civil servants in implementing risk management actions: Public officials' risk management capacity is one of the most concerned capabilities of local authorities, whether a local government undertakes multi-hazard planning, or risk analysis, local authorities should have a sufficient number of staff with appropriate education and training, and be informed of the hazards they face in their respective jobs.

- Capability to operate technical facilities for disaster risk management: Localities can be provided by the government or equip themselves with critical infrastructure, require special capacity, or operate other facilities that technical layer effectively of the staff and civil servants.

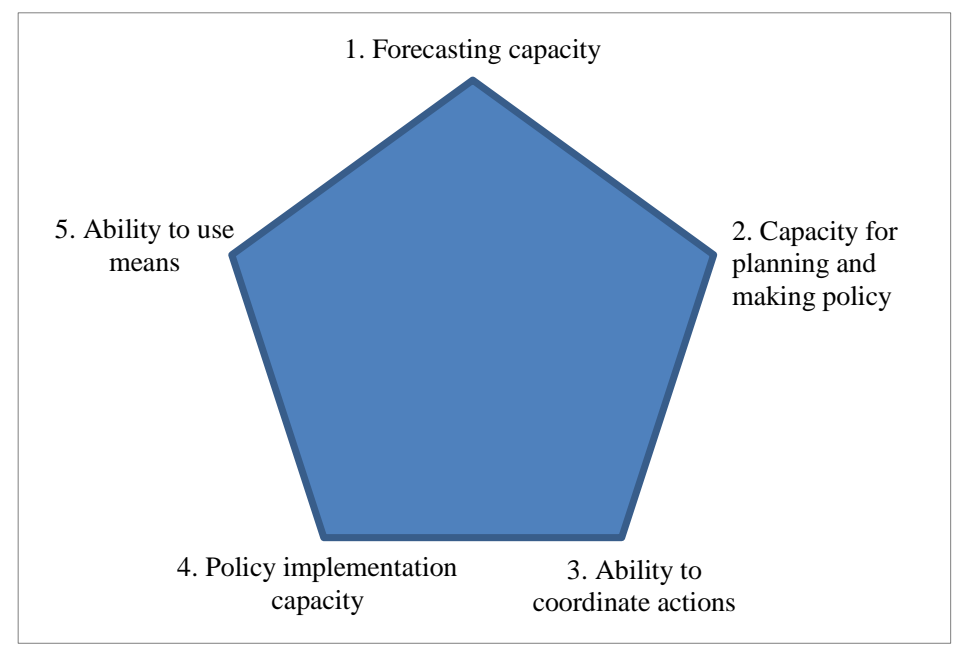

Figure 1. Disaster risk management capacity of local government

\section{Natural disasters in the Central Highlands, Vietnam in the period 2015 -2020}

Clause 1, Article 3 of the Law on Natural Disaster Prevention and Control stipulates that a natural disaster is an abnormal natural phenomenon that can cause damage to people, property, the environment, living conditions and socio-economic activities. including: storm, tropical depression, whirlwind, lightning, heavy rain, flood, flash flood, inundation, landslide caused by rain or flow, land subsidence due to rain, flood or runoff, water surge [14, 15]. Among the manifestations of natural disasters, droughts and floods frequently occur in the Central Highlands, the most serious damage is drought and flood. The period 2015-2020 is shown on the map as follows (Figure 2):

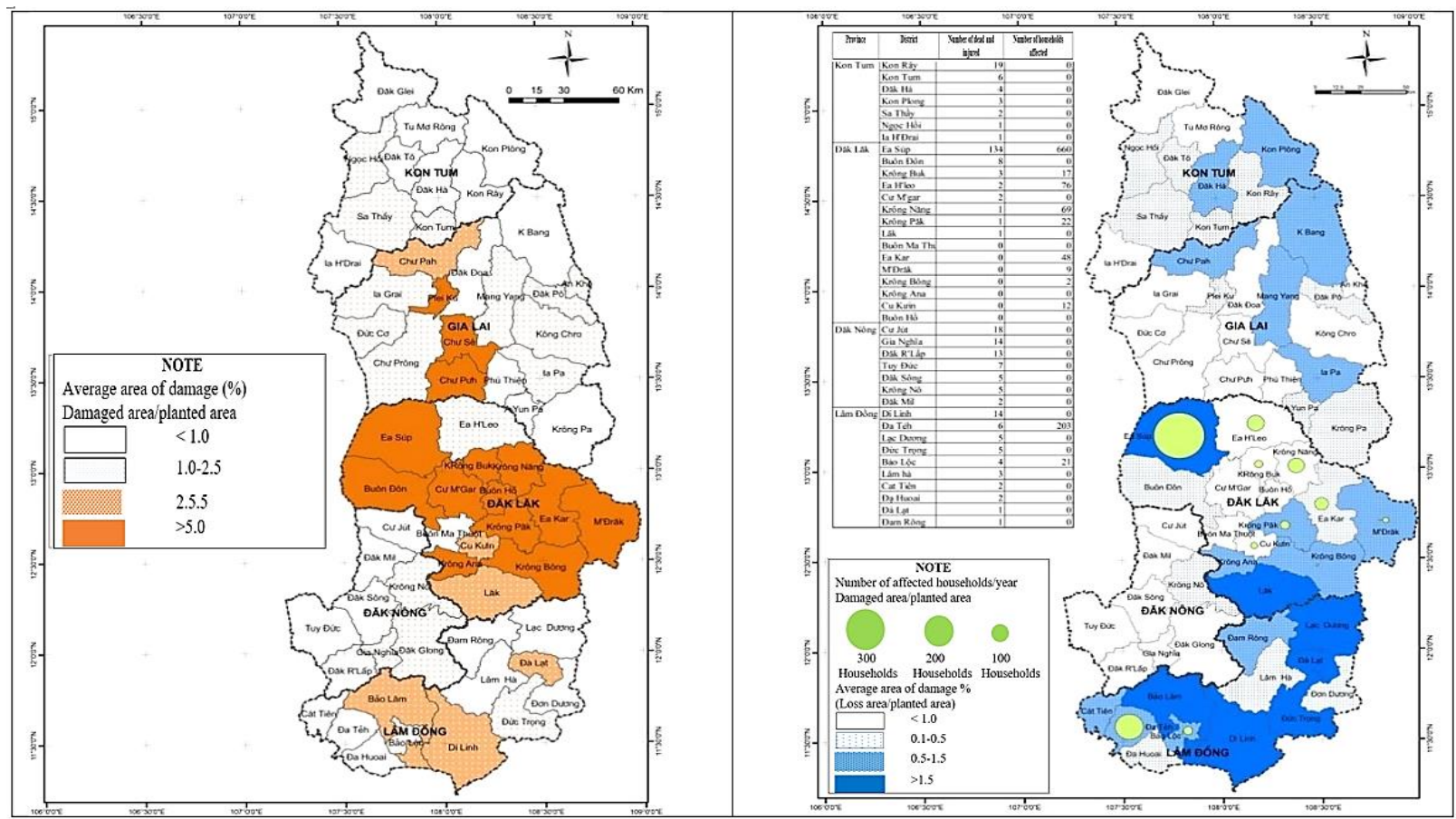

Figure 2. Disaster map of the Central Highlands provinces from 2015-2020 [16] 
From the beginning of the year to August 12, 2019, under the impact of natural disasters caused by floods, 10 people died; 4 people were injured; 3,717 houses were flooded; 789 houses had to be relocated. 18,382ha of rice and crops were flooded; 703ha of perennial crops, 2,558ha of annual crops, 1,083ha of fruit trees were damaged; 299 cattle, 120,741 poultry were killed and swept away [17] of the five provinces, Dak Lak province suffers from the most severe shortages of surface water and groundwater, with a total water shortage of 362 million $\mathrm{m}^{3}$ per year in low water years, many districts in the past being relatively abundant in terms of water resources. When the forest has not been destroyed is currently facing a serious water shortage, more than 25 million $\mathrm{m}^{3} / \mathrm{year}$. Lam Dong province has two districts with serious shortage of surface water in the year of low water, the total water demand is 128 million m3/year. Based on the above assessment, the respective districts in the 5 provinces are classified according to the amount of water shortage as follows:

Table 1. Statistics on the number of districts facing water shortage [16]

\begin{tabular}{|c|c|c|c|c|c|c|c|c|c|c|c|c|c|}
\hline \multirow[b]{2}{*}{ Year } & \multirow[b]{2}{*}{ Provinces } & \multicolumn{3}{|c|}{$<0.5$ million $\mathrm{m}^{3} /$ year } & \multicolumn{3}{|c|}{ 0.5 10 million $\mathrm{m}^{3} /$ year } & \multicolumn{3}{|c|}{ 10 25 million $\mathrm{m}^{3} / \mathrm{year}$} & \multicolumn{3}{|c|}{ >=25 million $\mathrm{m}^{3} /$ year } \\
\hline & & $\begin{array}{c}\text { Face } \\
\text { water }\end{array}$ & $\begin{array}{l}\text { Ground } \\
\text { water }\end{array}$ & Total & $\begin{array}{l}\text { Face } \\
\text { water }\end{array}$ & $\begin{array}{l}\text { Ground } \\
\text { water }\end{array}$ & Total & $\begin{array}{c}\text { Face } \\
\text { water }\end{array}$ & $\begin{array}{l}\text { Ground } \\
\text { water }\end{array}$ & Total & $\begin{array}{l}\text { Face } \\
\text { water }\end{array}$ & $\begin{array}{l}\text { Ground } \\
\text { water }\end{array}$ & Total \\
\hline \multirow{6}{*}{$\begin{array}{c}\text { Year of little } \\
\text { water }\end{array}$} & Kon Tum & 8 & 9 & 7 & 2 & 1 & 3 & 0 & 0 & 0 & 0 & 0 & 0 \\
\hline & Gia Lai & 7 & 7 & 3 & 10 & 10 & 14 & 0 & 0 & 0 & 0 & 0 & 0 \\
\hline & Đắk Lắk & 6 & 3 & 2 & 5 & 5 & 5 & 1 & 4 & 1 & 3 & 3 & 7 \\
\hline & Đắk Nông & 5 & 8 & 5 & 3 & 0 & 3 & 0 & 0 & 0 & 0 & 0 & 0 \\
\hline & Lâm Đồng & 2 & 11 & 1 & 5 & 1 & 6 & 3 & 0 & 3 & 2 & 0 & 2 \\
\hline & Total & 28 & 38 & 18 & 25 & 17 & 31 & 4 & 4 & 4 & 5 & 3 & 9 \\
\hline \multirow{5}{*}{$\begin{array}{l}\text { Years of plenty } \\
\text { of water }\end{array}$} & Kon Tum & 10 & 10 & 10 & 0 & 0 & 0 & 0 & 0 & 0 & 0 & 0 & 0 \\
\hline & Gia Lai & 8 & 8 & 4 & 9 & 9 & 13 & 0 & 0 & 0 & 0 & 0 & 0 \\
\hline & Đắk Nông & 8 & 6 & 6 & 0 & 2 & 2 & 0 & 0 & 0 & 0 & 0 & 0 \\
\hline & Lâm Đồng & 7 & 11 & 6 & 4 & 1 & 5 & 1 & 0 & 1 & 0 & 0 & 0 \\
\hline & Total & 42 & 37 & 28 & 16 & 19 & 24 & 4 & 5 & 8 & 0 & 1 & 2 \\
\hline
\end{tabular}

(Unit: district)

\subsection{Damage Caused by Drought}

The area of crops damaged by drought in the Central Highlands provinces has increased continuously in recent years (Figure 3), of which Dak Lak province is the province that suffers serious damage caused by drought and excessively high water demand indicates that a loss of control over groundwater development is taking place.

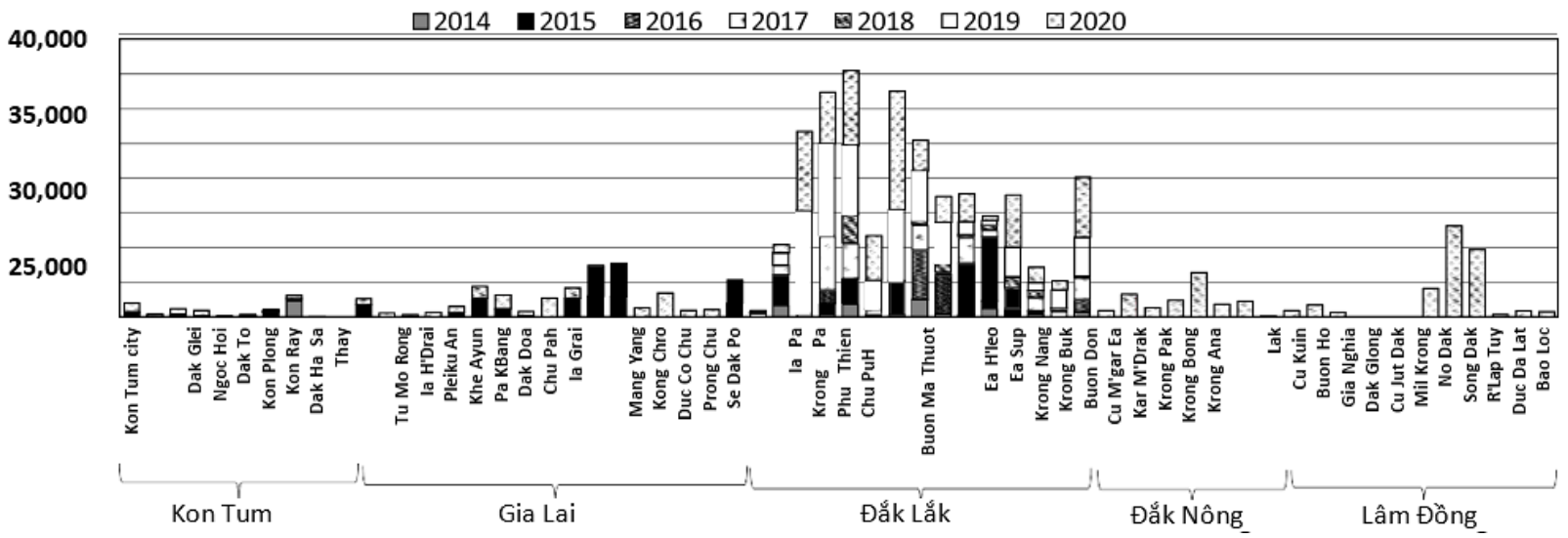

Figure 3. Area of crops damaged by drought in the Central Highlands provinces from 2014 to 2020 [16]

In the past 5 years, the unusual movements of natural disasters have increased surface runoff, leading to a decrease in the resilience of groundwater. Currently, the total exploitation potential of groundwater in the Central Highlands is about 5,400 million $\mathrm{m}^{3} / \mathrm{day}$, the total amount of groundwater consumption in the region is increasing, the exploitation is over-exploited and unpredictable. Poor infrastructure maintenance and development leads to more severe damage from natural disasters, because rural areas are isolated during floods and people lack water for daily use during droughts [18]. 


\section{Actions Taken to Respond to Natural Disasters by the Central Highlands Provinces}

The authorities of the provinces in the Central Highlands have taken actions to respond to natural disasters through quite specific actions such as improving the capacity and quality of forecasting for hydrometeorology; programs to ensure population safety in flooded areas; planning, zoning, preventing and avoiding flash floods and landslides; planting forests to cover bare land, bare hills and mountains, protecting watershed protection forests; improve water storage and supply capacity of reservoirs, consolidate irrigation canal systems; change the structure of livestock and plants towards sustainability in accordance with the natural conditions of the region; strengthen information, communication and education on disaster prevention, avoidance and mitigation for the population community under the motto of four on the spot (on-the-spot command, on-site forces, on-site vehicles and materials) and on-site logistics); training to improve rescue capacity for natural disaster prevention and control forces at all levels; purchase more equipment, means of boats, canoes to improve the efficiency of on-site rescue for facilities [19, 20].

Currently, provinces and districts in the Central Highlands have established a Steering Committee for Natural Disaster Prevention and Control. At the provincial level, the Steering Committee has 122 members, coming from the Department of Agriculture and Rural Development, the Department of Natural Resources and Environment, the Department of Transport, the Department of Construction, the Department of Health, the Department of Labor and Invalids. Social Affairs, Department of Planning and Investment, Department of Finance, presidents of mass organizations. At the district level, this number is 1,400 staff. The members of the Steering Committee are responsible for the preparation and implementation of disaster prevention and recovery activities. Periodic and specific activities in 5 provinces will not be the same, depending on the existing provincial budget. However, all 5 provinces have common problems such as limited budget, degraded irrigation works, lack of disaster early warning equipment, etc.

According to the Socio-Economic Development Plan for the period 2015-2020, each province has developed an infrastructure development plan for each sector, in which priority projects have been selected. All five provinces in the Central Highlands consider infrastructure development as a driving force for economic growth. However, the results achieved by Gia Lai, Dak Nong and Lam Dong on irrigation systems have not been as planned, both in terms of system and region. Kon Tum has almost achieved its goal. Dak Lak has achieved (or is close to) the target in all areas, but the GPDP of Dak Lak has not reached the expected level, which shows the infrastructure development of the province from 2015 to 2020 does not contribute to economic activities effectively.

The provinces all have priority projects to improve people's living standards through the implementation of development projects in irrigation, water supply, flood prevention, road, industry, electricity, etc. However, the scope of priority projects is not entirely consistent with the current situation on water resource management and disaster prevention. All districts in each province are classified as target districts, while the number and project costs for each district vary from province to province. Regarding flood prevention, the amount and budget account for less than $1 \%$ of the total investment in the Central Highlands, even in heavily affected provinces such as Dak Lak and Lam Dong. Dak Lak province has the highest potential for irrigation development among the five provinces, but there is no plan to develop irrigation systems until 2025. Lam Dong has prepared the most ambitious plan for irrigation development, but it requires more resources than it currently has. In general, the infrastructure in the Central Highlands is still not developed enough to meet the current situation, especially considering the development plans of the irrigation sector.

Before the impacts of natural disasters, on March 17, 2021, the Prime Minister of Vietnam issued Decision No. 379/QD-TTg approving the national strategy for natural disaster prevention and control up to 2030, with a vision to 2050 [21], then on April 6, 2021 the Prime Minister of Vietnam issued Decision No. 553/QD-TTg approving the public awareness project and community-based disaster risk management, by 2030 [22]. Following the direction from the Government, right from the beginning of 2021, the heads of governments of the Central Highlands provinces have shown very high political determination with the announcement of devoting resources to investment for renewable recovery, protect forests, preserve the green color of the great plateau, protect the ecological environment, mitigate climate change and enrich resources [23]. However, since the direction from the Government, these statements have not been included in the agenda as well as policy making to respond to natural disasters, and the current project plans have not met the requirements. To meet the needs of the people, resources are being focused on developing infrastructure. In addition, local priority projects after 2020 have not yet met actual needs [16]. Therefore, development orientations based on research results are considered realistic and will help the Central Highlands provinces more, when compared with the current priority projects.

The plan to respond to and minimize the impact of drought is one of the important objectives of the local authorities, which has not yet been effective. Every year, plans to respond to natural disasters in general and drought in particular are developed every year. However, the plans are more administrative than practical to deal with local problems [18]. 


\section{Discussion}

From the actual local governance capacity of the Central Highlands provinces in responding to natural disasters, it is possible to draw some comments and assessments about the situation of responding to natural disasters in the Central Highlands in recent years such as:

Firstly, the income of people in the Central Highlands has increased significantly in recent years, due to the investment from projects, people expand the production area to plant industrial crops, but this growth is not sustainable. Due to the lack of vision and strategic planning in local governance, investment projects, mineral exploitation, migration, etc. are quite fragmented, between economic development and economic development. The economy and stability of the people's living environment are not included in the overall local governance strategy, making the natural environment unbalanced, the relationship and the order of the structure in the planning and construction of infrastructure lacks linkage, so when a disaster occurs, these structures do not seem to support each other, which inevitably leads to an increase in the scale and nature of the disaster. At present, the response to natural disasters does not seem to be effective, especially when natural disasters in the Central Highlands are becoming more and more severe, and the loss of life and property has increased. One of the important principles of good local governance is mobilizing the participation of the people, the stakeholders involved in the decision making and implementation process, where the participation of the people seems to be not significant.

Second, the government's attention to the people's livelihood and social life has not been given good attention, leading to migration. When the living environment is turned upside down due to natural disasters, people, not only local people but also people in other areas of the country lose their homes, they have to migrate and find new places to live in the Central Highlands. What other choice do they have to go deep into protection forests, special-use forests and as a result, natural forests have been narrowed to places for people to live and develop production. In the period 2005 to 2017, the Central Highlands provinces had 58,846 free immigrant households with about 220,000 people and this situation is expected to continue [24], but so far the government has not come up with a satisfactory solution to put an end to this reality. Forests have been destroyed, the over-exploitation of groundwater to develop industrial crops has resulted in prolonged drought and drought, $15-70 \%$ shortfall in river flows, and a shortage of some rivers over $85 \%[25,26]$. Due to prolonged drought and hot weather, the whole region currently has about 2,685 million hectares of forest with high risk of fire [27].

Third, the authorities in the Central Highlands have established disaster prevention agencies, but through the recent developments and specific actions that the authorities have taken to respond to natural disasters, it has been shown that The way to react to reality when there is a natural disaster occurs is quite slow, because the leadership and civil servants in these agencies do not have enough capacity in responding to natural disasters [18]. Moreover, when the government set up these agencies, these agencies do not seem to have the role and function to advise the government in project construction activities, mineral exploitation, migration status, etc. and settlement of people, in the government's work for the construction of protection works, irrigation works, etc. to prevent from afar the risks of natural disasters. Develop disaster response plans corresponding to disaster risk levels; natural disaster prevention and control plan; plans to respond to big floods, strong storms, super storms, landslides, flash floods, etc., have not yet met practical requirements.

Fourth, construction investment projects related to natural disaster prevention have not shown transparency and effectiveness, usefulness and connectivity when in use, so many works that have not been completed were completed with little effect. And also due to the lack of a role in community supervision, especially people as beneficiaries of decisions and related departments, many new constructions that have been put into use have been damaged or not; repaired into ruins [28]. Transparency and publicity in the mass media about works to respond to natural disasters, droughts, and irrigation works on the mass media are still overlooked, so the role of the people know, people discuss, people check in these issues are quite fuzzy.

Fifth, the attention to improving local governance capacity and disaster response capacity of leaders and civil servants is not commensurate with practical requirements. In the way of local governance, there is a lack of comprehensiveness and synchronization from economic development, attention to social life, and people's livelihoods are relatively fragmented. Actions implemented in response to good and bad disasters are necessary but not feasible, have high political will but lack of practical action capacity, lack of forecasting capacity, leading to adverse reactions situational nature, when there are natural disasters, it is embarrassing and passive, so great damage to both people and property is unavoidable.

Strengthening local governance capacity in the Central Highlands of Vietnam in response to unusual natural disasters is inevitable, in order to respond to this trend, the following issues should be considered:

Firstly, to further strengthen the participation of the people in local decision-making. Local governance is associated with local affairs and the interests of local people, so the role of the people should be strongly promoted. The Constitution of Vietnam enshrines that the people exercise state power by direct democracy, by representative 
democracy, all state power belongs to the people $[14,15]$. This regulation sets forth requirements for the Central Highlands local government in performing the role of the people's mastery, the people must be known, discussed, examined, supervised and finally, the people must enjoy the benefits. This also confirms the motto that people know, people discuss, people do, people inspect, people monitor, people benefit from the Communist Party of Vietnam (2021) [29]. Propagating, disseminating and educating the people about the law so that people can clearly understand what the people know, what people can discuss and contribute ideas to in the process of promulgating local government's decisions, what people do decisions and affairs are examined; well implement the listing, publicity and transparency of socio-economic development programs, financial disclosure, mobilization of people's contributions. Encourage greater participation of state-owned enterprises, private economic organizations, non-profit organizations, voluntary organizations, associations and local community organizations in the policy process, in order to strengthen the relationship between local authorities and people [3].

Secondly, train leaders and civil servants at all levels of the Central Highlands government to have sufficient local management capacity, especially management capacity in response to natural disasters. Having innovative thinking, vision and scientific working methods; capable of synthesizing, analyzing and forecasting. Having practical capacity, grasping and basic understanding of the actual situation in order to concretize and effectively organize the implementation of the State's policies and laws in the assigned fields and areas of work. Dare to think, dare to do, dare to take responsibility and serve for the people. Modeling, gathering and promoting the synergy of the people, gaining the people's trust and support [30]. Building a system of monitoring, evaluation and appraisal of the people on the quality of cadres and civil servants as well as surveying people's satisfaction in public service activities will be an authentic measure to assess the ethics and capacity of the current local cadres and civil servants. In addition to the common standards, leaders and civil servants at all levels of the Central Highlands government must have their own management capabilities in responding to natural disasters in the Central Highlands, so it is necessary to regularly organize training courses. The seminar aims to exchange and learn experiences in forecasting, responding and handling emergency situations when natural disasters occur. In recent years, natural disasters have occurred in the Central Highlands with increasing frequency, scale and extent of damage [31], so the capacity to respond to natural disasters must also change.

Thirdly, be open, transparent and promote accountability of the government to the people in local development governance. The publicity and transparency in the use and investment of public resources in the construction of natural disaster prevention and control works and works serving the people's livelihood with specific examples for people to monitor. Many investment activities lack publicity, transparency, lack of supervision from the people, leading to unbalanced development, sometimes due to hot economic growth and the more economic activities develop, the higher the risk, caused by natural disasters can be even greater, especially in countries with asynchronous development in many aspects [32]. All 5 provinces of the Central Highlands have had thousands of irrigation works built with a huge amount of money but not working, even abandoned or just finished, damaged and degraded [28], lack of transparency is said to be the main reason that wastes the construction of many disaster prevention works but is not able to put them into operation [33]. Therefore, with investment projects and programs in the community, it is necessary to create a way to maximize and effectively mobilize the participation of the investment supervision board and the community, such as: the Inspection Board. People's Committee, Fatherland Front Committee and mass organizations in communes and wards, especially the participation of the entire people.

Fourthly, avoid the hot growth that leads to the destruction of forest resources. In the Central Highlands, there are dozens of solar power plants built to meet the demand for electricity as well as the licensing of construction projects to expand industrial parks, but many factories and projects encroach on the land [34]. Deforestation, especially of natural forest areas, has occurred on an average over the past 10 years, the rate of natural forest loss in the Central Highlands averages about 46,267 hectares [35]. For the development of the farm economy, growing industrial crops and industrial plants requires a large amount of water for irrigation, so the massive development has led to rampant groundwater exploitation, causing a serious decrease in groundwater levels in the Central Highlands [36]. Many scientists have warned that the Central Highlands will face catastrophic disasters due to deforestation, but this issue seems to have been ignored, the forest is still severely damaged. The Central Highlands government needs to focus on projects to develop industrial parks and farms to grow industrial crops in a sustainable way. There should be scientific calculations between economic and social development and changes in the environment so that disasters can be minimized.

Fifthly, determine the strategic vision, develop the master plan, and plan for the comprehensive development of the Central Highlands towards sustainability. Effective local governance is demonstrated through defining strategic visions, formulating master plans and development plans, and effectively exploiting and using local resources, especially natural resources such as forests and minerals. However, to avoid the massive exploitation of available resources, the most serious issue is the illegal exploitation of minerals taking place in special-use forests and protection forests, leading to the destruction of forests for service for mining purposes [37]. Environmental pollution and water pollution are happening on an increasingly widespread scale. These consequences are all due to ineffective local governance; lack of an overall strategy; lack of a long-term vision; and lack of clear planning between economic 
development and the protection of natural and forest resources. Developing a system of irrigation protection works without scientific character. If the Central Highlands wants to develop sustainably, it is necessary to pay attention to building a strategic vision, building a comprehensive development master plan and plan, and it is necessary to change the current way of local governance so that it can respond proactively and actively to the unusual and increasingly fierce developments of natural disasters that the people are suffering.

Sixthly, all levels of government in the Central Highlands need to guide and promote the role of the people in forest protection. It is necessary to consider and develop regulations so that people living in special-use forests and protection forests can share benefits from the forest, such as participating in forest protection and enjoying the benefits of the protection policy. Forestry and forest development have the right to access the forest, exploit non-timber forest products, intercropped products under the forest canopy, but do not affect the conservation of forest ecosystems. At the same time, it is necessary to have specific regulations on principles, authority and time in the implementation of "closing the forest", "opening the forest door", forest allocation associated with land allocation, spiritual, religious and forest allocation to protect water resources for ethnic minority communities. Although legally, forest ownership and use rights have not been established, in practice, they are being informally regulated by traditional customary laws. In the opinion of the people, the forest is governed and owned by an "invisible" force, which is the gods and has an apparatus of dignitaries such as: magicians, heads of large families, etc., on behalf of the people. The gods govern the spiritual forest to protect the forest against acts of desecration. In addition, ethnic minorities also use another form of spiritual forest management and protection, which is by means of customary law as well as regulations on the responsibilities of members of the spiritual forest to protect the forests of their members.

\section{Conclusion}

Natural disasters are becoming a serious problem for the Central Highlands, causing great obstacles to people's livelihoods and lives. Therefore, it is especially urgent to improve local government governance capacity to be proactive in policy making and effectively implement policies to be proactive in responding to natural disasters. However, improving the governance capacity of local governments seems to have many shortcomings. To meet the requirements that are actually being set for the governance of local governments in the Central Highlands, institutional capacity, organizational capacity, implementation capacity, technical capacity, and political capacity must be further enhanced. In particular, it is necessary to mobilize more people's participation in local decision-making. The contingent of leading cadres and civil servants at all levels of the Central Highlands government must be trained and retrained to have sufficient local management capacity, especially management capacity in response to natural disasters. The government must be open, transparent, and accountable. It should avoid hasty behavior in economic development leading to the destruction of forest resources and needs to have the capacity to plan strategic visions, develop master plans, and comprehensively develop the Central Highlands towards sustainability. Therefore, developing governance capacity for local governments in the Central Highlands provinces in response to natural disasters is an urgent task not only now but also in the long term.

\section{Declarations}

\subsection{Author Contributions}

All authors contributed to the design and implementation of the research, to the analysis of the results, and to the writing of the manuscript. All authors read and approved the final manuscript.

\subsection{Data Availability Statement}

The data presented in this study are available in article.

\subsection{Funding}

The authors received no financial support for the research, authorship, and/or publication of this article.

\subsection{Institutional Review Board Statement}

Not applicable.

\subsection{Informed Consent Statement}

Not applicable.

\subsection{Declaration of Competing Interest}

The authors declare that there is no conflict of interests regarding the publication of this manuscript. In addition, the ethical issues, including plagiarism, informed consent, misconduct, data fabrication and/or falsification, double publication and/or submission, and redundancies have been completely observed by the authors. 


\section{References}

[1] Phuong, N. T., (2018). Local governance from theory to practice. Ha Noi Social Science Publishing House, Hanoi, Vietnam.

[2] Thuy, Đ. T. T. (2016). Local governance - a method to improve the quality and efficiency of local government operations. Available online: https://tcnn.vn/news/detail/32141/Quan_tri_dia_phuong_phuong_thuc_nang_cao_chat_luong_hieu_qua_hoat _dong_cua_chinh_quyen_dia_phuongall.html (accessed on February 2021).

[3] Ly, L. T. (2019). Factors affecting the effectiveness of local governance in Vietnam. Available online: https://tcnn.vn/news/ detail/42871/Nhung-yeu-to-anh-huong-den-hieu-qua-quan-tri-dia-phuong-o-Viet-Nam.html (accessed on February 2021).

[4] Halfani, M., (1996). The challenge of urban governance in East Africa: responding to an unrelenting crisis. In: Cities and governance: new directions in Latin America, Asia and Africa. Toronto: Centre for Urban and Community Studies, 183-186.

[5] Wilson, R. H. (2000). Understanding local governance: an international perspective. Revista de Administração de Empresas, 40(2), 51-63. https://doi.org/10.1590/s0034-75902000000200006.

[6] Bell, S., (2002). Economic Governance and Institutional Dynamics. Oxford University Press, Melbourne, Australia.

[7] Anh, L. (2014). Local governance and citizen participation. Available online: https://daibieunhandan.vn/quan-tri-dia-phuongva-su-tham-gia-cua-nhan-dan-304419 (accessed on March 2021).

[8] Adger, W. N., Arnell, N. W., \& Tompkins, E. L. (2005). Successful adaptation to climate change across scales. Global Environmental Change, 15(2), 77-86. https://doi.org/10.1016/j.gloenvcha.2004.12.005.

[9] Hai, T. N., \& Van, Q. N. (2021). Servant leadership styles: A theoretical approach. Emerging Science Journal, 5(2), $245-256$. https://doi.org/10.28991/esj-2021-01273.

[10] Ndreu, A. (2016). the Definition and Importance of Local Governance. Social and Natural Sciences Journal, 10(1), 5-8. https://doi.org/10.12955/snsj.v10i1.730.

[11] Hai, T. N., Van, Q. N., \& Tuyet, M. N. T. (2021). Digital transformation: Opportunities and challenges for leaders in the emerging countries in response to covid-19 pandemic. Emerging Science Journal, 5(Special Issue), 21-36. https://doi.org/10.28991/esj-2021-SPER-03.

[12] Grindle, M. S. (2009). Going Local. doi:10.1515/9781400830350.

[13] Mai, H., (2017). Renovate and improve local governance capacity. State Management Magazine, Volume 256, 42.

[14] National Assembly of Vietnam, (2013). Law on Natural Disaster Prevention and Control, Law No. 33/2013/QH13, June 19, 2013, Hanoi.

[15] National Assembly, (2013). Constitution of the Socialist Republic of Vietnam, November 28, 2013, Hanoi, Vietnam.

[16] Vietnam Institute of Social Sciences - Central Highlands Institute of Social Sciences (VISS), (2021). Report No. 01/BCKHXH, May 21, 2021 summarizes the results of the disaster research team in the Central Highlands, the Central Highlands.

[17] Triu, N. (2019). Nearly 1,000 billion in damage due to natural disasters in the Central Highlands and the South. Available online: https://baophapluat.vn/thiet-hai-gan-1-000-ty-do-thien-tai-o-tay-nguyen-nam-bo-post314793.html (accessed on March 2021).

[18] Nhung, Đ. T. K. (2021). Research on scientific basis and propose solutions to regulate and distribute inter-regional and interriver basins in Central Highlands and South Central region, code KC.08/16-20. Institute of Planning Irrigation.

[19] Huy, N. V. (2013). Improve the community's capacity to prevent and respond to natural disasters. Available online: https://kontum.gov.vn/pages/detail/22577/Nang-cao-nang-luc-phong-ngua-va-ung-pho-voi-thien-tai-cho-cong-dong.html (accessed on February 2021).

[20] Huy, N. V. (2015). To limit damage caused by natural disasters in the Central Highlands. Available online: http://baodaklak.vn/channel/3684/201505/de-han-che-thiet-hai-do-thien-tai-gay-ra-o-tay-nguyen-2388210/ (accessed on March 2021).

[21] Prime Minister of Vietnam (PMVN), 2021. Decision No. 379/QD-TTg, March 17, 202 approving the national strategy for natural disaster prevention and control up to 2030, with a vision to 2050, Hanoi, Vietnam.

[22] Prime Minister of Vietnam (PMVN), 2021. Decision No. 553/QD-TTg dated April 6, 2021 approving the project of public awareness raising and community-based disaster risk management, by 2030, Hanoi, Vietnam.

[23] Dung, N. (2021). Opportunity for the Central Highlands to develop breakthroughs. Available online: https://nhandan.vn/tintuc-kinh-te/van-hoi-de-tay-nguyen-phat-trien-but-pha-638362/ (accessed on January 2021).

[24] Lich, K. (2019). The Central Highlands "stretched" to carry free migrants. Available online: http://cand.com.vn/Phong-su-tulieu/Tay-Nguyen-gong-minh-ganh-dan-di-cu-tu-do-537450/ (accessed on March 2021). 
[25] Long, V., \& Long, H. (2020). The consequences of deforestation are becoming more and more serious. Available online: https://laodong.vn/xa-hoi/nhung-he-luy-tu-mat-rung-ngay-cang-nghiem-trong-817416.ldo (accessed on February 2021).

[26] Vu, K. (2020). Central and Central Highlands are struggling with severe drought. Available online: https://laodong.vn/xahoi/mien-trung-va-tay-nguyen-dang-vat-lon-voi-han-han-khoc-liet-797940.ldo (accessed on March 2021).

[27] Ly, N. C. (2020). More than 2.6 million hectares of forests in the Central Highlands and South Central Coast are at high risk of fire. Available online: https://nhandan.vn/tin-tuc-xa-hoi/hon-2-6-trieu-ha-rung-o-tay-nguyen-va-duyen-hai-nam-trung-bo-conguy-co-chay-cao-450356/ (accessed on March 2021).

[28] Thanh, V. (2021). Wasted billions of irrigation works in the Central Highlands. Available online: http://cand.com.vn/dieu-tratheo-don-ban-doc/Lang-phi-nhung-cong-trinh-thuy-loi-tien-ty-o-Tay-Nguyen-632857/ (accessed on March 2021).

[29] Nhân Dân Newspaper (2021). Documents of the 13th National Congress of Deputies. National Politics Truth, Vietnam.

[30] The Central Committee of the Communist Party of Vietnam, (2017). Regulation No. 89-QD/TW dated August 4, 2017 framework of title standards, orientation of the framework of criteria for evaluation of leading and managerial cadres level, Hanoi, Vietnam.

[31] Voice of Vietnam: Radio Network. (2019). Central Highlands: 10 years of natural disasters and man-made disasters. Available online: https://vov.vn/tin-24h/tay-nguyen-10-nam-thien-tai-va-nhan-hoa-943583.vov (accessed on April 2021).

[32] Chinh, T. (2020). Specialized model towards “disaster management.”. Available online: https://baotainguyenmoitruong.vn/ mo-hinh-chuyen-trach-huong-toi-quan-tri-thien-tai-307371.html (accessed on April 2021).

[33] Bac, C. (2019). Find solutions for trillions of irrigation projects without irrigation land. Available online: https://vov.vn/xahoi/tim-giai-phap-cho-cong-trinh-thuy-loi-nghin-ty-khong-co-dat-tuoi-958470.vov (accessed on March 2021).

[34] Trung, B., \& Tuan, T. (2021). Confused about solving solar power mistakes in the Central Highlands. Available online: https://laodong.vn/xa-hoi/lung-tung-giai-quyet-cac-sai-pham-dien-mat-troi-o-tay-nguyen-930081.ldo (accessed on March 2021).

[35] Binh, G. (2020). The Central Highlands loses 46,267 hectares of natural forest each year. Available online: https://thanhnien.vn/thoi-su/tay-nguyen-mat-46267-ha-rung-tu-nhien-moi-nam-1249451.html (accessed on March 2021).

[36] Phuc, H., Kien, Đ., \& Nguyen, D. (2018). The Central Highlands broke the industrial tree battle. https://www.sggp.org.vn/taynguyen-vo-tran-cay-cong-nghiep-bai-2-he-luy-day-chuyen-524976.html (accessed on March 2021).

[37] Hao, V., \& Ton, V. (2017). Mineral management in the Central Highlands. https://www.thiennhien.net/2017/06/01/quan-lykhoang-san-vung-tay-nguyen/ (accessed on March 2021). 